\title{
FEATURES OF CREATIVITY AND INNOVATION DEVELOPMENT IN STUDENTS AT SECONDARY AND HIGH SCHOOL
}

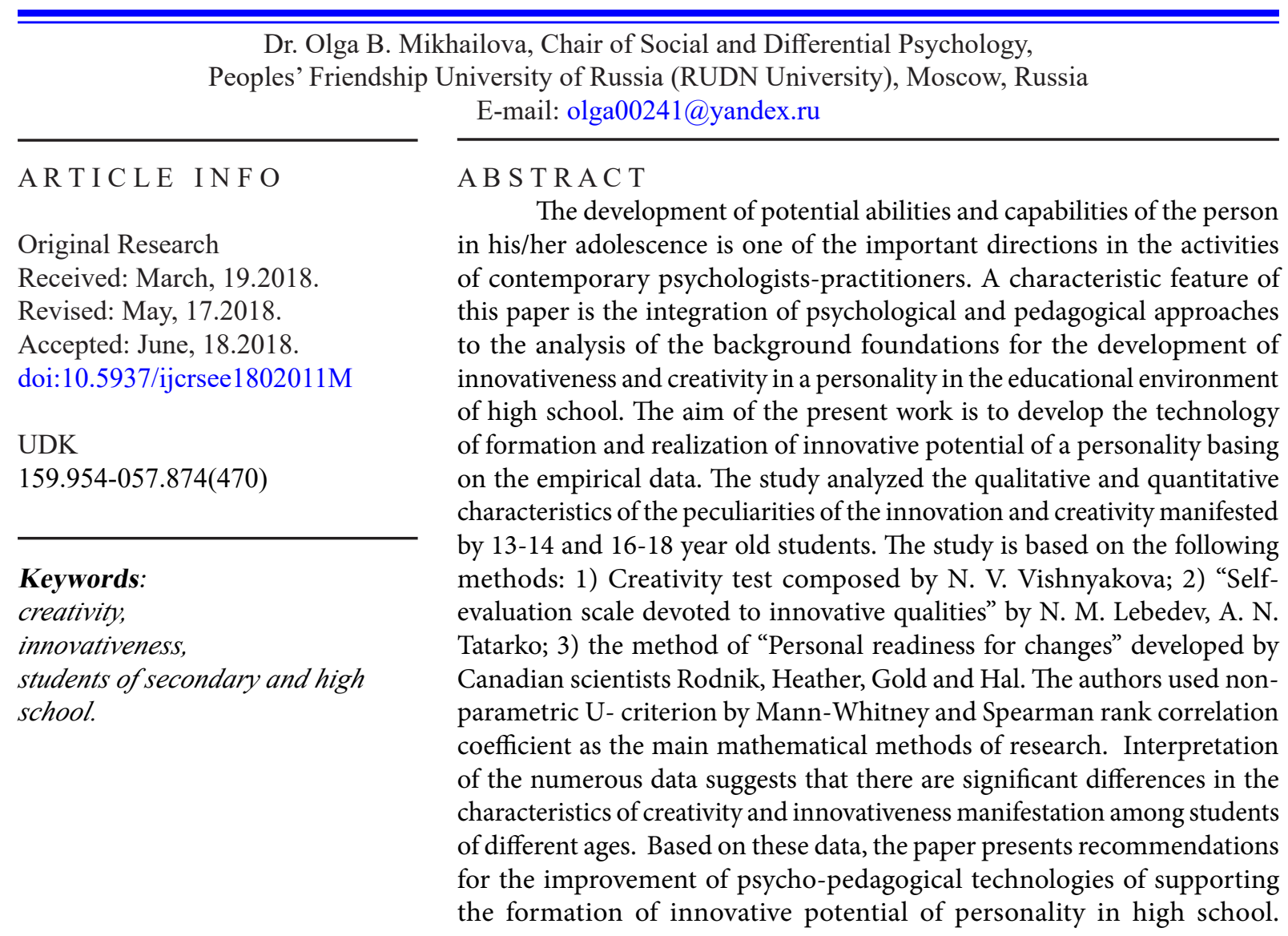

(C) 2018 IJCRSEE. All rights reserved.

\section{INTRODUCTION}

New challenges of social development in the twenty-first century require any person to manifest the personal qualities and abilities to adapt to the dynamically changing conditions of life and work. The reality of professional activity makes a modern specialist demonstrate not only intellectual and creative abilities, but also such personal qualities as the speedy introduction of new ideas and projects, leadership, responsibility, ability to work in a

Dr. Olga B. Mikhailova, Chair of Social and Differential Psychology, Peoples' Friendship University of Russia (RUDN University), Moscow, Russia, E-mail: olga00241@yandex.ru

This work is licensed under a Creative Commons Attribution - NonCommercial - NoDerivs 4.0. The article is published with Open Access at www.ijcrsee.com team, initiative, ability to achieve results with limited time and manufacturing resources.

Potential abilities are developed in the process of learning, communicating and acting within secondary and higher educational environment. Therefore, modern technologies of psychological and pedagogical support of the personality development in the framework of the educational process also should be focused on the results of the research devoted to creativity and innovativeness among adolescents and students of high school.

The strategy of Russia's development until 2020, elaborated by the state, obliges the practitioners of the educational system to develop the younger generation's ability for social activity, rapid adaptability under the changes in the surrounding reality, willingness to generate new ideas, their adoption and implementation for the benefit of the society.

To implement this strategy it is necessary to study the peculiarities of high school 
students' personality traits' manifestations, to develop and implement new educational technologies that contribute to the formation of potentially effective personal capital for future generations.

The potential of the individual can be considered as the optimum combination of personal traits and abilities that are manifested in certain types of direct practical activity within the social processes.

On the basis of the systematic approach to the study of individual properties and traits, an innovative potential is considered as the sum of personal resources (assets), embodied in the interconnected kinds of activity (Kirton, 1984; Damanpour, 1987; Goldsmith and Hofacker, 1991; Lebedeva, 2002; Novković Cvetković and Stanojević, 2017). The structure of the innovative potential of the personality consists of the following types of activity:

- value-motivational (constructive effectiveness),

- active (innovativeness) and

- intellectual (creativity).

The innovative potential of a personality is the integrated set of aptitudes, abilities and qualities of a man, realized as the outcome of his inclusion into the innovative activity. They consist of interrelated and mutual components: constructive effectiveness, innovativeness and creativity expressed in intellectual and valuemotivational kinds of activity (Mikhailova, Kudinov, and Jerez, 2015; Mikhailova and Kaminskaya, 2016).

The study of creativity from the position of a psycho-economic model by D. Robinson and M. Ranko allows one to present creativity as a result of economic and time resources that the society finds necessary to spend on the development of the creative potential. In this case, the decision depends on the level of development of the society itself, and creativity is considered as the ratio of investments, risk and benefits (Gupta, Wilemon, 1996; Robinson, Marshall, Stamps, 2005; Tsai, 2018).

In their research, the proponents of the systematic approach to the study of creativity, D. Simonton and M. Csikszentmihalyi, focus on the study of various determinants of creative potential, social and cultural human environment, which contribute to the manifestation and development of creativity. M. Csikszentmihalyi emphasizes the study of the relationship between a man, the subject area of his activities and the environment. He believes that the educational environment consists of cultural and social components. In the process of active activities, a developing person inter- acts with the socio-cultural components of the educational environment, which influence the formation of personality traits and qualities in a constructive way (Csikszentmihalyi, 1999; Simonton, 1997).

E. Torrance believes that creativity is associated with the problem solving process and includes sensitivity to problematic situations; search, selection and formulation of a problem; generating hypotheses, methods of problems' solution; hypothesis testing; finding and formulating solutions; interpretation and popularization of the results (Torrance, 1988).

Despite the fact that theoretical and experimental investigations devoted to the manifestations of creativity in different periods of personal development have already been carried out, the problem of creativity being connected with innovativeness and the peculiarities of the formation of these personal traits has been considered extremely little in Russian science. Still, creativity and innovation are the foundations of its formation and implementation in the context of the studies devoted to the human capital formation and development (Kudinov, Kudinov, Kudinova, and Mikhailova, 2017).

The development of personal traits is greatly influenced by the educational system, professionalism of the teacher, culture of the educational space, whereto the child is immersed during the most important stages of his/her development. The following guidelines in capacity building and gaining the capital for future generations are relevant in the strategy and tactics of modern education: personal development, social activity, humanitarian and technical education, physical and psychological resilience. An important direction in the development of personal potential is the formation of activity, which is based on innovation (Hofstede, 1983; Valacich, Dennis and Connolly, 1994; Paulus and Yang, 2000; Stošić and Stošić, 2013).

In our latest research, innovativeness is considered to be an integrated set of personal qualities, the main of which are: adaptability, independence, persistence, willingness to take risks for the sake of achievement, openness to something new, intuition, constructive leadership, creative direction and positivity (Lebedeva, Bushina, and Cherkasova 2013; Mikhailova and Kaminskaya, 2016). Considering innovativeness as a set of personal traits, we believe that the most favorable periods for these traits' formation is teenage and senior school age.

The peculiarities of formation and de- 
velopment of a personality in adolescence and senior school age groups always remain under scrutiny in the psychological science. The dynamically changing environment of socialization forms the new characteristics of personal traits' manifestation in these age periods.

In adolescence period, both physiological and psychological changes take place, which lead to changes in behavior. According to D. B. Elkonin's classification, adolescence covers the period from $10-11$ to $14-15$ years (Elkonin, 2001). It is often called transitional, critical, emphasizing the difficulties of adolescents' personal development.

The person's development in this age is a transition from childhood to independent and responsible adulthood. This is an intermediate state between childhood and adulthood. Together with the quest for the self-conscience development, the formation of the personality's ideal, there appears a propensity for reflection, development of volitional qualities, necessity of self-assertion, self-perfection, self-determination. The primary new formation of this period, from the standpoint of $\mathrm{L}$. $\mathrm{S}$. Vygotsky, is the social consciousness transported inside, i.e., the formation of identity. Its appearance creates the conditions for further personal development.

The individual's physical maturation gets completed in senior school age. According to D. B Elkonin's classification this age (from 15 to 18 years) is considered to be early adolescence (Elkonin, 2001). According to E. Erickson's studies, the central process of this age is the formation of personal identity, the discovery of one's own "self" (Erickson, 1968).

The development of the creativity phenomenon in adolescence and senior school age groups is studied in the works by J. Guilford, E. Torrance, D. Simonton, D. B. Bogoyavlenskaya, O.A. Klyueva, P. I. Chernetsova, L. D. Malceva, T. I. Vinogradova, E. I. Nikolaeva, E. M. Belyaeva and other researchers (Guilford, 1959; Torrance, 1988; Simonton, 1997; Bogoyavlenskaya, 2002; Bogoyavlenskaya, 2011; Bogoyavlenskaya and Klyueva, 2012; Malceva, 2013; Chernetsova and Vinogradova, 2015; Nikolaeva and Belyaeva, 2015).

\section{MATERIALS AND METHODS}

The described aspects explain the purpose and hypotheses of the present study. In our opinion, there are peculiarities of connection between the forms of creativity and inno- vativeness in adolescents and senior students, also creativity and innovativeness manifestations will have typical age-explained differences.

The study involved 96 secondary school students. Of these, 48 students studied in 7-8 grades (13-14 years) and 48 high school students studied in 10-11 grades (16-18 years). By gender the sample is almost equal. In the group of adolescents, 23 boys and 25 girls participated in the study, and in the group of high school students there were 24 boys and 24 girls. The study was conducted on the basis of school № 14 of Moscow South West Autonomous Area. The research was organized and the data was collected with the active support of a social psychology Master's graduate, L. V. Petrushina.

The following research methods were used: 1) Creativity test by N. V. Vishnyakova (Kaptsov, Kolesnikova, 2011); 2) "Selfevaluation scale for ones' innovative traits" by N. M. Lebedev, A. N. Tatarko (Lebedeva, Bushina, Cherkasova, 2013); 3) The method of "Personal readiness for changes" developed by Canadian scientists Rodnik, Heather, Gold and Hal. The translation and initial testing of this method was conducted by N. Bazhanova and G. L. Bardier (Bazhanova, 2005). As the main mathematical methods of research we used non-parametric Mann-Whitney U- criterion and Spearman's rank correlation coefficient. The statistical data processing was performed using the SPSS 20.0 computer program.

\section{RESULTS}

In the process of qualitative and quantitative analysis of the investigated data the following results were demonstrated by a group of secondary school students. Creativity indicators in adolescents (students of 7-8th grades) are higher than those of high school students (students of 10-11th grades). The results of the qualitative analysis clearly show that secondary school students demonstrate higher results on scales of creative thinking, curiosity, originality (Figure 1). 


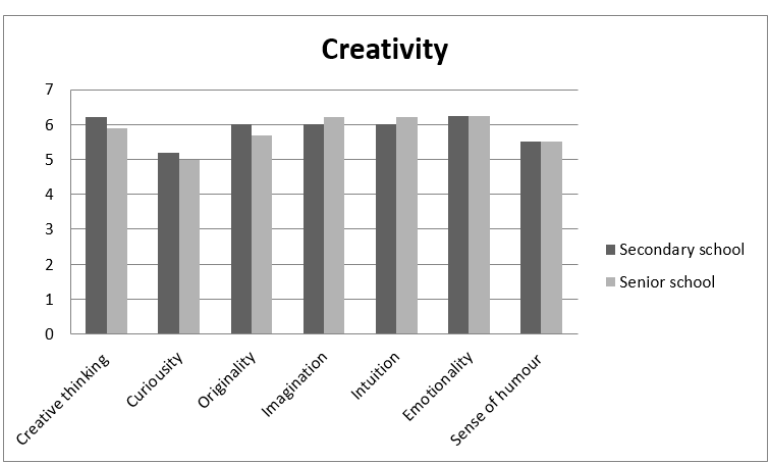

Figure 1. Comparison of the "Creativity" test results in groups of secondary and high school students

According to the results of the method "Self-assessment of one's innovative traits", creativity scale results turned out to be higher among students of teenage group (Figure 2).

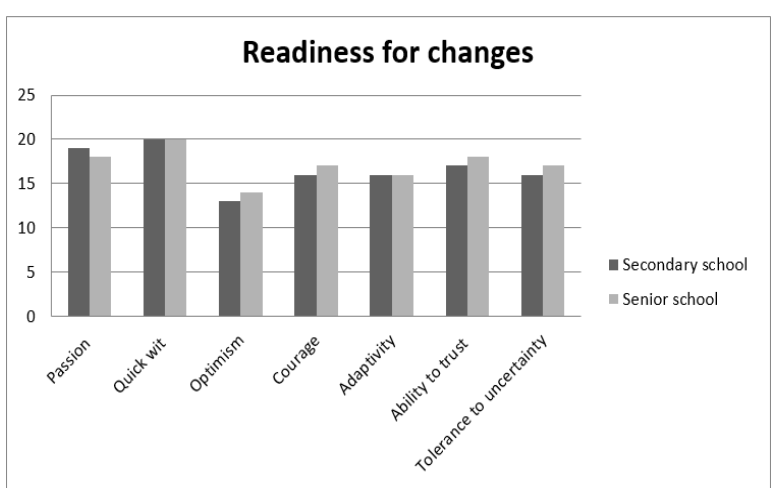

Figure 2. The results of the scale "Self esteem of innovative traits" in groups of secondary and high school students

The data obtained allow us to conclude that adolescence is dominated by intellectual activity, expressed by characteristic features of creativity. The results of rank correlation analysis for all the scales of the used methods also showed that significant links could be discovered in terms of originality - optimism, emotionality - courage. Besides, in addition to the results of the general index of innovativeness in adolescents are associated with indicators of the passion scale in the test "Creativity". The results of correlative analysis allow to conclude that the group of adolescents is dominated by the emotional component of the intellectual activity of the individual (Table 1).
Table 1. The results of rank correlation analysis for all techniques in groups of adolescents $(n=48)$

\begin{tabular}{cll}
\hline $\begin{array}{c}\text { № of } \\
\text { the pair }\end{array}$ & \multicolumn{1}{c}{ Scale name } & Value \\
\hline 1 & "adaptability" - "courage" & .369 \\
\hline 3 & "originality"-"optimism" & .384 \\
\hline 4 & "emotion"-"courage" & .391 \\
\hline 5 & $\begin{array}{l}\text { "orientation towards the future" } \\
\text {-"tolerance for ambiguity " }\end{array}$ & .390 \\
\hline 6 & $\begin{array}{l}\text { "general index of } \\
\text { innovativeness"-"passion" }\end{array}$ & .402 \\
\hline 13 & "optimism"- "originality " & .384 \\
\hline 14 & "courage"-"emotion" & .391 \\
\hline
\end{tabular}

Note: $* *$ - significance level $p<.01$

In their manifestations of innovativeness, the adolescents demonstrated significant connections on the scales of tolerance for ambiguity and orientation towards the future (Table 1). Thus, secondary school students tend to have a more reserved attitude to the semantic foundations of the future. According to the results of "Personal readiness for change" technique, the adolescents have higher indicators on the scales passion and resourcefulness that testifies to the prevailing emotiveness of the people in this age group (Figure 3).

However, in general, the results of innovativeness indicators in the group of secondary school students were lower than those of high school students. Indicators on the scales risk for success, orientation towards future, the general index of innovativeness appeared to be higher among seniors (Fig.2). The results of the qualitative analysis of "Personal readiness for change" technique, senior students also demonstrated higher indexes on the scales optimism, courage, confidence, tolerance for ambiguity. The findings suggest that senior students develop the activity, which is expressed by the indicators of growing innovativeness of the individual (Figure 3 ).

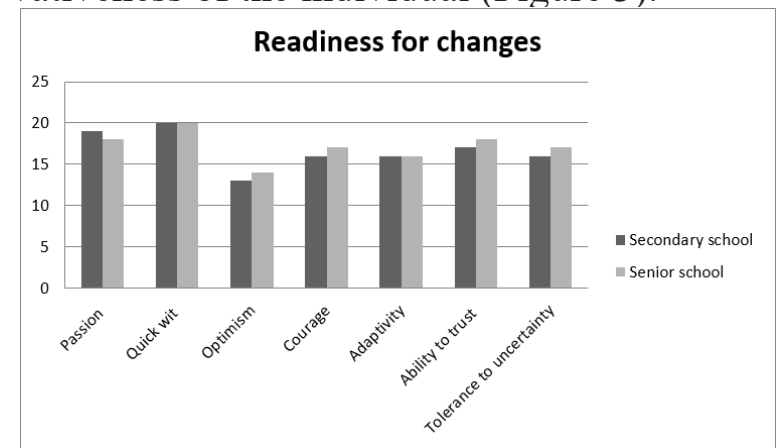

Figure 3. The results of enquiry on the technique "Personal readiness for changes" among secondary and high school students 
The results of correlative analysis allow to conclude that more statistically significant correlations between the scales of creativity and the general index of innovativeness were discovered in the group of high school students. Statistically significant links on the scales of passion, emotion, creativity and innovativeness are expressed (Table 2). Activity intensity among high school students expressed by characteristics of the individual innovativeness is manifested in connections between quick wit, creativity, creative thinking, orientation towards the future and the indexes of the general index of innovativeness (Table 2). The conclusion to be drawn according to the data obtained through the analysis of the rank correlation results is that the indicators of innovativeness are developing with age.

Table 2. The results of rank correlation analysis for all techniques in a group of high school students $(n=48)$

\begin{tabular}{|c|c|c|}
\hline $\begin{array}{l}\text { № of } \\
\text { the pair }\end{array}$ & Scale name & Value \\
\hline 5 & "emotion”-“passion" & .479 \\
\hline 6 & $\begin{array}{l}\text { "creative thinking" - “quick } \\
\text { wit" }\end{array}$ & .397 \\
\hline 7 & "creative thinking"-“optimism" & .433 \\
\hline 8 & "creativity"-"passion" & .371 \\
\hline 9 & "creativity" - "resourcefulness" & .458 \\
\hline 10 & «creativity» - «ability to trust» & .405 \\
\hline 11 & $\begin{array}{l}\text { "the risk for the sake of } \\
\text { success"-"resourcefulness" }\end{array}$ & .471 \\
\hline 12 & $\begin{array}{l}\text { "orientation for the future" - } \\
\text { "resourcefulness" }\end{array}$ & .462 \\
\hline 13 & $\begin{array}{l}\text { "general index of } \\
\text { innovativeness"-"passion" }\end{array}$ & .426 \\
\hline 14 & $\begin{array}{l}\text { "general index of } \\
\text { innovativeness" - } \\
\text { "resourcefulness" }\end{array}$ & .618 \\
\hline 15 & $\begin{array}{l}\text { "general index of } \\
\text { innovativeness"-“cconfidence " }\end{array}$ & .496 \\
\hline 16 & $\begin{array}{l}\text { "creative thinking and } \\
\text { intuition" }\end{array}$ & .435 \\
\hline 17 & $\begin{array}{l}\text { "creativity" - "creative } \\
\text { thinking" }\end{array}$ & .388 \\
\hline 18 & $\begin{array}{l}\text { "orientation towards future" - } \\
\text { "sense of humor " }\end{array}$ & .410 \\
\hline
\end{tabular}

High school students are more focused on the future, more resourceful, more optimistic. In this age group the connection between creativity, ability to trust and the general index of innovativeness are expressed, which indicates the growth of activity involvement of the individual in the openness of communication and trust in information, as well as readiness to apply it in creative projects.

Interestingly, when orienting towards their future high school students demonstrate a sense of humor. Therefore the graduates are positive about the fulfillment of their potential. Despite the growing prevalence of innovativeness indicators in the studied sample of high school students the connection between general creativity and abilities to creative thinking are sufficiently expressed (Table 2 ).

Despite the fact that the results of the qualitative analysis in the values on all scales in methods used in the study revealed differences in the manifestations of creativity and innovativeness in the studied groups, the results of mathematical analysis with the use of U - criterion of Mann-Whitney showed no such marked difference. The significant differences in the manifestations of innovativeness and creativity at the statistical level were obtained only in the creative thinking and orientation toward the future (Table 3 ).

Table 3. The indicators of significant differences in the U criterion by Mann-Whitney between the two studied groups

\begin{tabular}{lcccc}
\hline Ranks & & & & \\
\hline \multirow{2}{*}{$\begin{array}{l}\text { The names of scales and } \\
\text { methods }\end{array}$} & $\mathrm{N}$ & $\begin{array}{c}\text { Average } \\
\text { rank }\end{array}$ & $\begin{array}{c}\text { The sum } \\
\text { of the } \\
\text { ranks }\end{array}$ \\
\hline \multirow{2}{*}{$\begin{array}{l}\text { The creative } \\
\text { thinking }\end{array}$} & 1 & 48 & 55.96 & 2686.00 \\
\cline { 2 - 5 } & 2 & 48 & 41.04 & 1970.00 \\
\hline & Total & 96 & & \\
\cline { 2 - 5 } Creativity & 1 & 48 & 51.24 & 2459.50 \\
\cline { 2 - 5 } & Total & 96 & 45.76 & 2196.50 \\
\hline Orientation & 1 & 48 & 39.80 & 1910.50 \\
\cline { 2 - 5 } $\begin{array}{l}\text { towards the } \\
\text { future }\end{array}$ & 2 & 48 & 57.20 & 2745.50 \\
\hline $\begin{array}{l}\text { General index } \\
\text { of }\end{array}$ & 1 & 48 & 44.83 & 2152.00 \\
\cline { 2 - 5 } innovativeness & Total & 96 & & \\
\cline { 2 - 5 } & & 48 & 52.17 & 2504.00 \\
\hline
\end{tabular}

\section{DISCUSSION}

The obtained results allow to conclude that, in general, secondary school students have higher rates of intellectual activity expressed by characteristics of creativity, more pronounced tendency to creative thinking along with greater emotionality and originality in their intellectual work. This age group is characterized by lower results in terms of innovativeness.

The sample of high school age has a large focus onto the future and higher indexes on all the parameters of innovation. However, the growing involvement in the activity, expressed by the innovativeness displaces intel- 
lectual activity and indicators of creativity in the senior school age become lower. Probably, orientation towards future, positive pragmatic perception of their own activity, emerging practice-oriented intuition and the increasing reproductive thinking are able to displace originality and curiosity typical of intellectual activity and adolescence in general.

In order to maintain creativity and development of innovativeness it is important to develop new psychological technologies of teaching process organization. Modern technologies are based on the expansion of forms and methods of interactive learning, educational design modeling, based on a methodologically sound optimal combination of reproductive and problem - searching methods of teaching in their interaction.

An important direction in the strategies of educational design is the development of intellectual and enthusiastic activity for students to independently find solutions to educational problems, to form abilities for self-transformation and self-development by means of properly organized collective cooperation that would stimulate critical thinking, constructive engagement, new ideas promotion, social creativity in action and group enthusiasm.

The basic technologies of creativity and innovativeness development in secondary school students can be the practice of interactive learning and the strategy of educational process organization with the optimum combination of methods. In this sense, the interactive methods are rightly called the promising technologies of the XXI century that have future in the changing educational environment of the informational society. Interactive learning is a form of cognitive activity organization, which can be defined as dialog learning, in which interaction of educational process participants is taking place. The technologies of interactive learning are based on modeling of practical situations, the organization of role-playing games for collaborative problem solving. A joint project appears in the process of communication, here each member of the group contributes. It is important to exclude the dominant influence of one of the group members or some specific idea.

Interactive learning involves different forms of teaching process organization: 1) formation of a new experience and its theoretical understanding through its application in practice; 2) development of a joint independent activity, when the participants' experience and knowledge serve as a source of mutual learning and mutual communication.
For the effective organization of interactive communication in the learning process it is important to possess the technology of didactic design of the learning process on the basis of optimal combination of methods. In recent years, the scientific literature increasingly often uses the phrase 'pedagogical design' borrowed from foreign sources. This concept is regarded as a (Eng.: Instructional Design, Instructional Systems Design, ISD, French: Ingénierie pédagogique) which is the scientific direction connected with the development of the most effective, efficient and comfortable ways, methods and training systems that can be used in the educational process.

The relevant direction in educational design is the optimal combination of the methods in the structure of interactive forms of learning applied in secondary schools. The developmental aspect of this educational design is forms and methods of development, not only relating to cognitive processes, but also to the students' socially significant personal traits, because the development of social intelligence is an important basis for the person's successful self-realization in the future. In the process of learning, the problem of cognitive and personal traits development is represented in the form of specific objectives: to teach students to analyze, to identify the main thing, to compare, to build an analogy, to generalize and systematize, to prove and disprove, to define and explain concepts, to pose and solve problems, to actively support new ideas of their own and of the others' under the constructive cooperation in a team of peers.

The main didactic goal of the optimal combination of the reproductive and problem - searching methods of teaching in the interaction is the development of intellectual and enthusiastic activity for the students to independently find solutions for educational problems, to form abilities of self-transformation and self-development through inner freedom, critical thinking, the creation of individual ways of action through the practice of suggesting new ideas, social awareness of action, responsibility, efficiency, group activity.

\section{CONCLUSION}

When designing interactive forms of learning based on an optimal combination of the training methods one needs to master the ways of educational process management, to influence the controlled entities by the scientific justification of planning, organization 
and control of their activities. The most important indicator of a teacher's organizational effectiveness is his ability to efficiently use the class time. The second indicator is the organization of such an educational process in which students can and, most importantly, want to effectively apply their knowledge in reality. The main way to increase the effectiveness of the educational design is the formation of teachers' abilities to choose the most significant, most important material for some specific class: - to identify the main ideas (in the training material); - to master the ways of didactic communication, based on the principles of relevance, accessibility, clarity on the background of emotional-motivational attractiveness of the material for the students; - to manage the practical organization of the students' independent activity.

When determining the optimal combination of methods for a specific type of class, one should use a systematic design that allows to divide the process into the following phases:

analysis - determining the purpose, form and content of the classes and, as a consequence, a reasonable choice of training methods' integration;

- design - defining the phases, activities in the class that help to properly use the sequence of methods' application;

- implementation - development of methods and didactic material;

- combination - connection of a lesson fragments into a unified whole;

- adjustment - monitoring the actions in real practice;

- analysis and self-analysis - assessment of the effectiveness of teaching methods' combination in a definite type of class;

- testing - checking the teaching process outcomes and the students' development in this system.

The educational effect of these forms of interactive learning based on the optimal choice of methods leads to the following results:

- High motivational activity of all the participants of educational process due to the presence of a common goal.

- Social interaction. Working in a small group, students will develop social interaction skills; they learn not only to express their ideas but also to listen to others; they develop emotional flexibility and persistence; they form the ability to manage their emotions, when everyone's opinion is perceived and evaluated by the group.

The development of personal traits, self- esteem boost. Everybody has the opportunity to learn how to play the leading role, and the role of an ordinary group member in a situation of group decision making, how to develop the ability to openly interact with others while preserving your own individuality.

- Building constructive communication skills of all participants of the educational process.

- Effective memorization of the didactic material through repetition and application of knowledge in practice, through the analysis of the problematic situation in the group from different points of view.

Immersing into the conditions of interactive learning, the students are involved in the process of organized self-development and the development of their classmates, helping them to analyze their mistakes and to overcome them.

This creates an opportunity for constructive interaction, in which the capacity for personal self-development is formed through social interaction. It is important to note that the main role in the development and maintenance of innovativeness is played by a pedagogical stimulation of these personal traits among peers. In modern educational conditions, it is very important to include the creation of motives-making conditions of activity, which is aimed at including the person with a leading position into social relations with the group. Special attention is given to psychopedagogical technologies of development of creative identity, based on civic identity, positive values and motivational priorities of personal and professional self-development. In addition, teenagers and high school students need to develop the skills of self-knowledge and self-potential as well as the abilities, skills of managing the enthusiastic activity based on collective interaction, cooperation and constructive communication.

\section{ACKNOWLEDGMENTS}

The article is made in the framework of the initiative of NIR No. 050422-0-000 "Personal Potential as a Basis of Self-Realization of a Subject in Multicultural Environment “, performed on the basis of social and differential psychology department of Peoples' Friendship University of Russia (RUDN University). 


\section{REFERENCES}

Bogoyavlenskaya, D. B. (2011). On Prognostics of Psychodiagnostics Method Creative Field. Psychology in Russia: State of the Art, 4, 39-52. https:// elibrary.ru/item.asp?id=17025810

Bogoyavlenskaya, D. B. \& Klyueva O. A. (2012). Discovering the Nature of Competitive Personality. Psychology in Russia: State of the Art, 5, 67-80. https://elibrary.ru/item.asp?id=21889710

Bogoyavlenskaya, D. B. (2002). Psychology of creative abilities. Moscow: Academia.

Bozhanova, N. A. (2005). Personal willingness to Change in the Context of the Study of the Phenomenon of «Pending» (Translation and testing questionnaire «Personal change-readiness survey»). Acta eruditorum, 2, 169-178

Chernecov, P. I. \& Vinogradova, T. I. (2015). Correlation of creativity and intelligense of teenagers. Siberian pedagogical journal, 1, 80-83. https:// elibrary.ru/item.asp?id=23065951

Csikszentmihalyi, M. (1999). Implications of a Systems Perspective for the Study of Creativity. Handbook of Creativity / ed. by R. J. Sternberg. Cambridge. Cambridge University Press, 313-335. https:// books.google.ru/books?hl=ru\&lr=\&id=d1KTE QpQ6vsC\&oi=fnd\&pg=PA313\&dq $=$ Csikszent mihalyi,+M.+(1999).+Implications + of $+\mathrm{a}+$ Syst ems +Perspective+for+the+Study+of+Creativity\&ots=FtZ10iqjuW\&sig=uqspf010uy9yflgivMjP 9P $\mathrm{x} 17 \mathrm{w} \&$ redir esc $=\mathrm{y} \# \mathrm{v}=$ onepage \& $\mathrm{q} \& \mathrm{f}=$ false

Damanpour, F. (1987). The Adoption of Technological, Administrative and Ancillary Innovations: Impact of Organizational Factors. Journal of Management, 13, 675-688. https://doi. org/10.1177/014920638701300408

Elkonin D. B. (2001). Psychology of human development, Moscow, Aspekt Press, 460.

Erikson, E. (1968). Identity: Youth and Crisis. W. W. Norton company INC, New York.

Goldsmith, R. E. \& Hofacker, C. F. (1991). Measuring Consumer Innovativeness. Journal of the Academy of Marketing Science. 19 (3), 209. 221. https://link.springer.com/article/10.1007/ BF02726497

Guilford, J. P. (1959). Traits of Creativity. Creativity and its Cultivation/ed. by H.G. Anderson. N. Y.: Harper.

Gupta, A K., \& Wilemon, D. (1996). Changing Patterns in Industrial R\&D Management. Journal of Product Innovation Management, 13, 497-511. https://doi.org/10.1111/1540-5885.1360497

Hofstede, G. (1983). Cultural Dimensions for Project Management. International Journal of Project Management, 1, 41-48. https://doi. org/10.1016/0263-7863(83)90038-8

Kaptsov, A. V., \& Kolesnikova, E. I. (2011). The methodical aspects of use of psychometric tests in degree designing. Vestnik of Samara humanitarian Academy. A Series Of "Psychology", 2 (10), 107-119. (In Russ.). https://elibrary.ru/item. asp?id $=16860285$

Kirton, M. J. (1984). Adaptors and Innovators -Why New Initiatives Get Blocked. Long Range Planning, 17 (2), 137-143. https://doi.org/10.1016/00246301(84)90145-6

Kudinov, S., Kudinov, S., Mikhailova, O., \& Kudinova, I. (2017). The role of persistence in students' self-realization. International Journal of Cog- nitive Research In Science, Engineering And Education (IJCRSEE), 5(2), 19-26. doi:10.5937/ IJCRSEE1702019K

Lebedeva, N. (2012). Implicit Theories of Innovativeness: Cultural Differences. Psychology. Journal of Higher School of Economics, 9(2), 89-106. https://elibrary.ru/item.asp?id=20147382 https:// psy-journal.hse.ru/en/2012-9-2/53397939.html

Lebedeva, N. M., Bushina, E. V., \& Cherkasova, L. L. (2013). Tsennosti, sotsial'nyy kapital i otnoshenie $\mathrm{k}$ innovatsiyam [Values, social capital and attitude to innovations]. Obshchestvennye nauki i sovremennost [Social sciences and modernity], 4, 28-41. https://elibrary.ru/item. asp? $\mathrm{id}=20166164$

Malceva, L. D. (2013). Akmeology of Education: From Creative to Innovative. Scientific search, (3), 5659. https://elibrary.ru/item.asp?id=20271685

Mikhailova, O. B., Kudinov, S. I., \& Jerez, K. G. M. (2015). Value-Motivational Characteristics of Innovativeness as Prospects for Successful SelfFulfillment. Mediterranean Journal of Social Sciences, 6(3 S2), 105. DOI: 10.5901/mjss.2015. v6n3s2p105

Nikolaeva, E. I., \& Beljaeva, E. M. (2015). Interrelation of adolescents' creativity and aggressiveness. Scientific opinion, 6, 161-166. https://elibrary.ru/item.asp?id=23728572

Novković Cvetković, B., \& Stanojević, D. (2017). Educational needs of teacher for introduction and application of innovative models in educational work to improve teaching. International Journal Of Cognitive Research In Science, Engineering And Education (IJCRSEE), 5(1), 49-56. doi:10.5937/IJCRSEE1701049N

Olga B. Mikhailova and Elina A. Kaminskaya, 2016. Gender Characteristics of the Students' Innovative Behavior. The Social Sciences, 11, 44834488. DOI: $10.3923 /$ sscience.2016.4483.4488 URL: http://medwelljournals.com/abstract/?doi $=$ sscience. 2016.4483 .4488

Paulus, P. B. \& Yang, H. C. (2000). Idea generation in groups: A basis for creativity in organizations. Organizational Behavior and Human Decision Processes, 82(1), 76-87. https://doi.org/10.1006/ obhd.2000.2888

Robinson Jr, L., Marshall, G. W., \& Stamps, M. B. (2005). Sales force use of technology: antecedents to technology acceptance. Journal of Business Research, 58(12), 1623-1631. https://doi. org/10.1016/j.jbusres.2004.07.010

Simonton, D. K. (1997). Creativity in personality, developmental, and social psychology: Any links with cognitive psychology. In T. B. Ward, S. M. Smith \& J. Viad (eds.), Creative Thought: An Investigation of Conceptual Structures and Processes. American Psychological Association. pp. 309-324 (1997) https://philpapers.org/rec/ SIMCIP

Stošić, L., \& Stošić, I. (2013). Diffusion of innovation in modern school. International Journal Of Cognitive Research In Science, Engineering And Education (IJCRSEE), 1(1), 5-13. Retrieved from http://www.ijcrsee.com/index.php/ IJCRSEE/article/view/144

Torrance, E. P. (1988). The nature of creativity as manifest in its testing. The nature of creativity: Contemporary psychological perspectives, 43. https://books.google.ru/books?hl=ru\&lr=\&id=Z Yo5AAAAIAAJ $\&$ oi $=$ fnd $\& p g=$ PA43\&dq $=$ Torra 
nce, ++ E. + P. $+(1988) .+$ The + Nature + of + Creativi ty + as + Maintest + in + Its + Testing. ++ In: + R. + J. + St ernberg $+($ Ed. $) .+$ The + Nature + of + Creativity. $+\mathrm{Ca}$ mbridge: + Cambridge + University + Press.\&ots $=$ Oe3kpyOrkg\&sig=9dsHws7sUxwslHxZote2-9 $0 \mathrm{~J} 4 \mathrm{cA} \&$ redir_esc $=\mathrm{y} \# \mathrm{v}=$ onepage $\& \mathrm{q} \& \mathrm{f}=$ false

Tsai, K. (2018). An empirical examination of the relationships among creativity, the evaluation of creative products, and cognitive style among Chinese undergraduates. International Journal Of Cognitive Research In Science, Engineering And Education (IJCRSEE), 6(1), 53-60. doi:10.5937/ijcrsee1801053T

Valacich, J. S., Dennis, A. R., \& Connolly, T. (1994) Idea generation in computer-based groups: A new ending to an old story. Organizational behavior and human decision processes, 57(3), 448-467. https://doi.org/10.1006/obhd.1994.1024 